\title{
Biosorption of nickel and cobalt from plant effluent by Sargassum glaucescens nanoparticles at new membrane reactor
}

\author{
A. Esmaeili • A. Aghababai Beni
}

Received: 4 August 2014/Revised: 10 November 2014/Accepted: 30 December 2014/Published online: 20 January 2015

(C) Islamic Azad University (IAU) 2015

\begin{abstract}
In this study, brown algae (Sargassum glaucescens) nanoparticles were prepared by using a planetary ball mill to remove nickel and cobalt. The biosorption reaction in the reactor was studied under different conditions of $\mathrm{pH}$, biosorbent dose, temperature, and retention time. The concentration of heavy metals was investigated after the fluid had passed through the membrane system. Algae nano-biosorbent was prepared using a planetary ball mill; scanning electron microscope and Brunauer-Emmert-Teller tests showed an average diameter of $95.75 \mathrm{~nm}$ and specific surface area of $11.25 \mathrm{~m}^{2} / \mathrm{g}$, respectively. A maximum biosorption efficiency equal to 93 and $91 \%$ was achieved for nickel and cobalt at $\mathrm{pH} 6$, temperature $35{ }^{\circ} \mathrm{C}$ with a retention time of $80 \mathrm{~min}$, and at biosorbent doses of 8 and $4 \mathrm{~g} / \mathrm{l}$. The kinetic data fit well by pseudo-first-order model, and equilibrium data of metal ions could be described well with the Langmuir and Dubinin-Radushkevich isotherm models. The calculated thermodynamic parameters showed that metal ion biosorption is feasible, endothermic, and naturally spontaneous.
\end{abstract}

Keywords Membrane reactor - Nanoparticle . Biosorption · Water treatment $\cdot$ Nickel $\cdot$ Cobalt

A. Esmaeili $(\bowtie) \cdot$ A. Aghababai Beni

Department of Chemical Engineering, North Tehran Branch, Islamic Azad University, PO Box 19585/936, Tehran, Iran

e-mail: akbaresmaeili@yahoo.com

\section{Introduction}

All living organisms require heavy metals in low concentrations, but high concentrations of heavy metals are toxic and can cause cancer (Koedrith et al. 2013). Nowadays the environment is threatened by an increase in heavy metals. Therefore, in recent years, the removal of heavy metals has become an important issue (Nurbaş Nourbakhsh et al. 2002). Methods for removing metal ions from aqueous solution mainly consist of physical, chemical, and biological technologies. Conventional methods for the removal of heavy metal ions from wastewater, such as chemical precipitation, flocculation, membrane filtration, ion exchange, and electrodialysis electrolysis, are often costly or ineffective for the treatment of low concentrations of pollutants (Wang and Chen 2009). Biological uptake is a promising approach that has been studied in the past decade. This process is a good candidate for replacing old methods (Pinto et al. 2011). High efficiency, removal of all metals even at low concentrations, being economical, and energy independence are the main advantages of biological uptake which present this process as a viable new technology (Bai and Abraham 2002). In our previous works, the absorption of copper, nickel, and cobalt by brown algae in a fixed bed reactor showed that brown algae are capable of removing over $80 \%$ of heavy metals from aqueous solutions (Esmaeili and Sadeghi 2014). Comparison of $\mathrm{Cr}(\mathrm{VI})$ adsorption by dried brown algae (Sargassum sp.) and by activated carbon from brown algae (Sargassum sp.) shows that dried brown algae are more effective than activated carbon (Esmaeili et al. 2012a). Also, Kleinübing et al. (Kleinübing et al. 2011) confirmed the possibility of nickel and copper biosorption by marine alga (S. filipendula) in a dynamic system. In addition, the removal of $\mathrm{Pb}$ (II) and 
$\mathrm{Hg}$ (II) was investigated by brown algae ( $S$. glaucescens) and red algae Gracilaria corticata. The results showed that brown algae have more potential to absorb heavy metals compared with red algae (Esmaeili et al. 2012a, c). The biosorption process is controlled by several parameters; Pahlavanzadeh et al. (2010) investigated nickel biosorption by various species of Iranian brown algae and have expressed that the most important parameters are $\mathrm{pH}$, temperature, and initial concentration. Of course, $\mathrm{pH}$ is of particular importance and is dependent on the functional groups of the adsorbent and metal ions. Montazer-Rahmati et al.'s (2011) and Liu et al.'s (2009) experiments have shown that the optimal $\mathrm{pH}$ for the biosorption of nickel by brown algae is 6 . However, the biosorption process in those works was conducted in batch systems within Erlenmeyer flasks, and new equipment was not designed for the biological uptake process. In the present research, a new membrane reactor was designed and built based on nano-biosorbents. Nonwoven fibers were used in this membrane reactor to reduce membrane fouling.

\section{Materials and methods}

\section{Materials}

Sargassum glaucescens (brown algae) were collected from the Persian Gulf from Queshm Island. Natural wool felt was prepared from The Cultural Heritage, Handicrafts and Tourism Organization of Shahre Kord. Sodium hydroxide and hydrochloric acid were purchased from Merck. Deionized water was used throughout this work.

\section{Preparation of biomass}

Brown algae ( $S$. glaucescens) were washed several times with distilled water in order to remove sand particles. The wet biomass was dried for 5 days at room temperature in a glass container. The biomass was dried for $12 \mathrm{~h}$ at $80{ }^{\circ} \mathrm{C}$ in an oven. Then, the algae were crushed to a particle size range of 100-500 $\mu \mathrm{m}$ using a kitchen mill (Pars Khazar GR-1.2.3P). Algae particles were further crushed using a planetary ball mill (Fara Pajouhesh Isfahan FP2) at $600 \mathrm{rpm}$ for $1 \mathrm{~h}$ until achieving a range of 30-300 nm.

\section{Process design}

As shown in Fig. 1, two slurry samples, containing nickel and cobalt, were collected from Shahre Kord hub for industry; the sludge slurry samples were driven into the primary settling tank; and after $2 \mathrm{~h}$, the liquid-solid phase was formed. The liquid phase was deposited into a stalactite column with a small pump, which was installed where the two phases interface (the membrane bed of stalactite column was made from two layers of natural felt, each with a thickness of $1 \mathrm{~cm}$ ), suspended particles from wastewater were filtered, and the wastewater was then collected. Biosorbent was added to $1,500 \mathrm{ml}$ of wastewater, and wastewater was transferred to the membrane reactor (the membrane reactor was designed and made in a cylindrical form with an internal diameter of $110 \mathrm{~mm}$ and height of $220 \mathrm{~mm}$ from polyethylene with a thickness of $8 \mathrm{~mm}$; membrane reactor was equipped with a stirrer and baffles. The baffles were made of four aluminum tubes, water passed through the baffles at different temperatures, so that the membrane reactors could achieve a heat transfer mechanism), biosorption reactor condition is turbulent, and heavy metal ions were adsorbed on the surface of biosorbent. After the biosorption process, the fluid was discharged and pumped into the bed of column stalactite to remove biosorbent (in this membrane bed, a layer of cotton was added between two layers of natural felt) (Esmaeili and Beni 2014).

Preparation and characterization of algae nanoparticles

FT-IR spectra in the range of 400-4,000 1/cm were used to determine the functional groups of brown algae ( $S$. glaucescens) nanoparticles (Thermo Scientific Nicolet 8700 FTIR spectrometer). The brown algae ( $S$. glaucescens) nanoparticle morphology after gold coating was studied using scanning electron microscope (SEM, LEO 435VP). Image processing software ImageJ was used to measure the nanoparticle diameter from the SEM micrographs. SEM analysis was performed on an SEM (KYKY-EM3200). The analytical conditions varied as follows: secondary electron detector mode (SE), magnification of 40,000 times, electron beam voltage of $25 \mathrm{kV}$, spot size of $4-5 \mathrm{~nm}$ at low pressure $\left(>10^{-6}\right.$ Torre $)$, and temperature of $25^{\circ} \mathrm{C}$. The sample was coated by gold sputtering prior to examination.

The specific surface area was determined using the Brunauer-Emmert-Teller method (BET, Sorptometer 1042). Heavy metal concentration in the sample solution was determined by atomic adsorption spectroscopy (Varian atomic adsorption 240). Algae biomass, before and after the biosorption, was examined by X-ray powder diffraction (Philips PW3040).

Batch biosorption studies

Three classes of batch biosorption experiments in the membrane reactor were carried out on 1,500 $\mathrm{ml}$ of waste- 


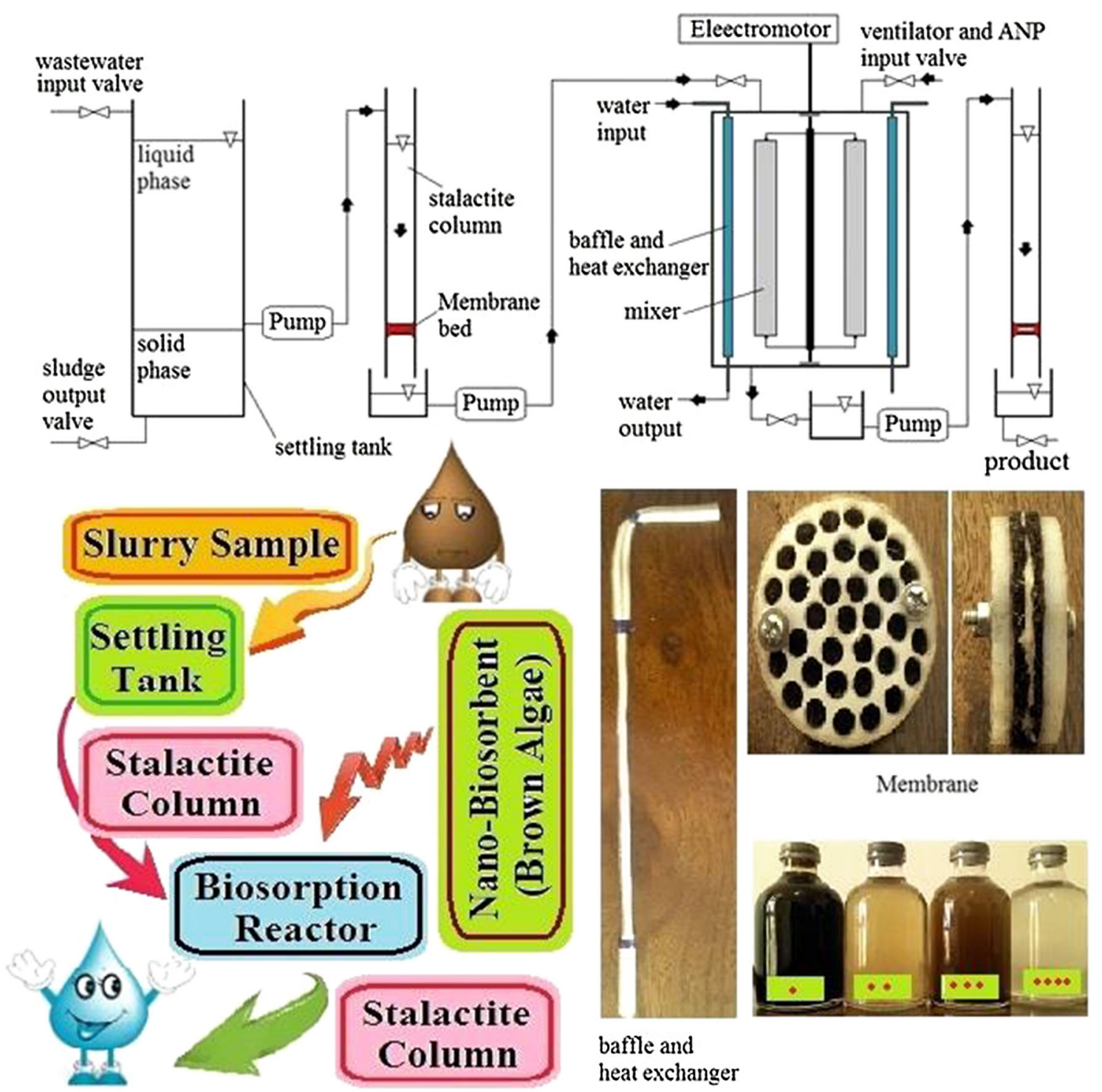

Fig. 1 Schematic of the biosorption process at biosorption reactor

water. The effects of $\mathrm{pH}$ (from 2 to 7 , adsorbent dose 10 and $4 \mathrm{~g} / \mathrm{l}$ for nickel and cobalt effluents, respectively), biosorbent dose (with 4, 6, 8, 10, $12 \mathrm{~g} / \mathrm{l}$ for nickel and with 2, 3, 4, 5, $6 \mathrm{~g} / \mathrm{l}$ for cobalt, $\mathrm{pH}$ 6), and retention time (from 10 to $120 \mathrm{~min}$ at different temperature conditions with optimal values of biosorbent dose and $\mathrm{pH}$ ) were investigated. The biosorption capacity $\left(q_{e}\right)$ was calculated using Eq. (1) (Esmaeili and Beni 2014):

$q_{e}=\frac{\left(C_{0}-C_{e}\right) V}{W}$

where $C_{0}$ is the initial concentration $(\mathrm{mg} / \mathrm{l})$ of nickel or cobalt, $C_{e}$ is any of the heavy metal ion concentrations $(\mathrm{mg} / \mathrm{l})$ at a given time, $V$ is the volume of the solution (l), and $M$ is the weight of the biosorbent $(\mathrm{g})$. The removal percentage was calculated using Eq. (2):

$R \%=\frac{C_{0}-C_{e}}{C_{0}}$

Statistical analysis

All statistical analyses were performed using MATLAB R2013b (8.2.0.701) software for Windows. The statistical significance of differences between values was assessed using the test. Error bars are indicated wherever necessary. 

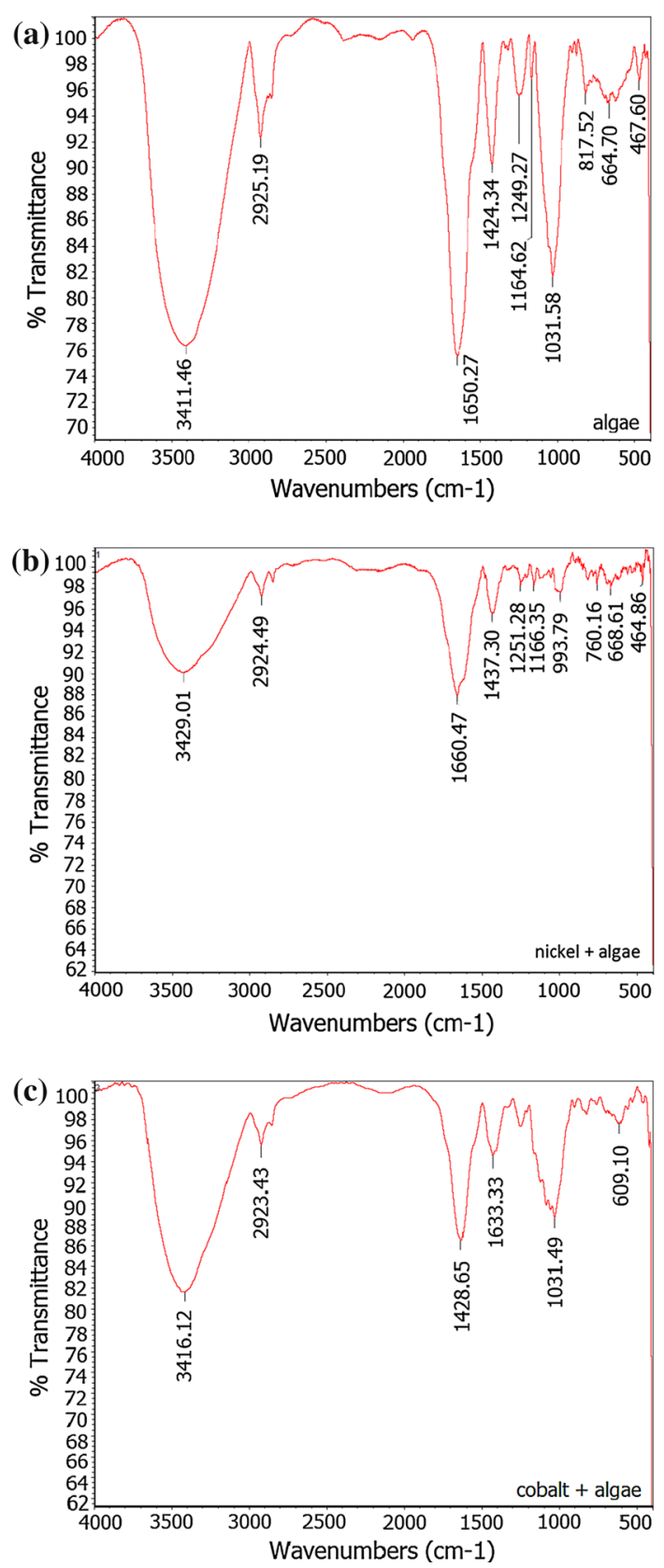

Fig. 2 a FTIR spectra of $S$. glaucescens nanoparticle before treatment. b After nickel wastewater treatment. c After cobalt wastewater treatment

\section{Results and discussion}

FTIR spectra, SEM, and BET characterization

Brown algae ( $S$. glaucescens) are mainly composed of $20-40 \%$ of the total dry weight alginate and some sulfated polysaccharides (Daneshvar et al. 2012). The FTIR spectra of algae biomass are shown in Fig. 2. The broad and strong vibration around $3,000-3,800 \mathrm{l} / \mathrm{cm}$ is indicative of $-\mathrm{OH}$ and $-\mathrm{NH}$ groups. The peaks at $2,854-2,9231 / \mathrm{cm}$ were assigned to the asymmetric and symmetric $\mathrm{C}-\mathrm{H}$ stretching vibrations of the aliphatic groups. The strong peak at $1,650 \mathrm{l} / \mathrm{cm}$ was attributed to $-\mathrm{C}=\mathrm{O}$ stretching vibration. The peak at $1,424 \mathrm{l} / \mathrm{cm}$ represents $-\mathrm{N}-\mathrm{H}$ bending vibration. The peak at $1,2491 / \mathrm{cm}$ is due to $-\mathrm{N}=\mathrm{O}$ stretching vibrations for the biomasses. The bands observed at 1,031-1,164 1/cm were assigned to C-O stretching vibration of alcohols and carboxylic acids. According to Fig. 3a, $\mathrm{b}$, the nanoparticles were produced using planetary ball mill at $600 \mathrm{rpm}$ for $1 \mathrm{~h}$ until particles were in the range of 30-300 nm. Average diameter of the nanoparticles was $95.75 \mathrm{~nm}$. Based on Brunauer-Emmet-Teller (BET), the obtained average surface area of nanoparticles was $11.25 \mathrm{~m}^{2} / \mathrm{g}$. Comparing Fig. $2 \mathrm{a}-\mathrm{c}$ shows that after the treatment of cobalt and nickel, the signal over 3,000 1/cm for Fig. 2a was broad and sharp but for Fig. 2b, c it was sharper. In Fig. 2b, cobalt metal had bonded with many $-\mathrm{OH}$ groups of alginate in algae, and in Fig. 2a, bonding had occurred with all $-\mathrm{OH}$. Figure $2 \mathrm{c}$ confirms the upper adsorption in FTIR, because intensity of signals from Fig. 2a, b decreased strongly. Charged groups such as carboxylate and hydroxyl present in the biopolymers of biomass cells are believed to be responsible for the sequestration of metal ions.

\section{Batch biosorption studies}

\section{Effect of initial solution $\mathrm{pH}$}

Figure $4 \mathrm{a}, \mathrm{b}$ shows that the biosorption of nickel and cobalt increased from $\mathrm{pH} 4.0$ to 6.0 and then decreased from 6.0 to 7.0 ; the optimum $\mathrm{pH}$ was determined to be approximately 6.0. Formation of anionic hydroxide complexes is the most likely explanation for the lower uptake at higher $\mathrm{pH}$ values.

Kalyani et al. (2004) have reported on biosorption at different $\mathrm{pH}$ values. This study further investigates the effects of $\mathrm{pH}$ on adsorption and bioreduction. The initial $\mathrm{pH}$ of the metal solution was observed to be an important parameter affecting adsorption of metal ions. The removal of nickel and cobalt increased with an increase in $\mathrm{pH}$ from 4.0 to 6.0 and then decreased to 7.0 , with an optimum $\mathrm{pH}$ of about 6.0 observed. The lower uptake at higher $\mathrm{pH}$ values is probably due to the formation of anionic hydroxide complexes. In another study, at low and high $\mathrm{pH}$ values, nickel had a higher redox potential and favored nickel bioreduction (Esmaeili et al. 2012b). In addition, 
Fig. 3 a Scanning electron micrographs of brown algae Sargassum glaucescens nanoparticle. b Frequency of brown algae nanoparticles diameter (a)

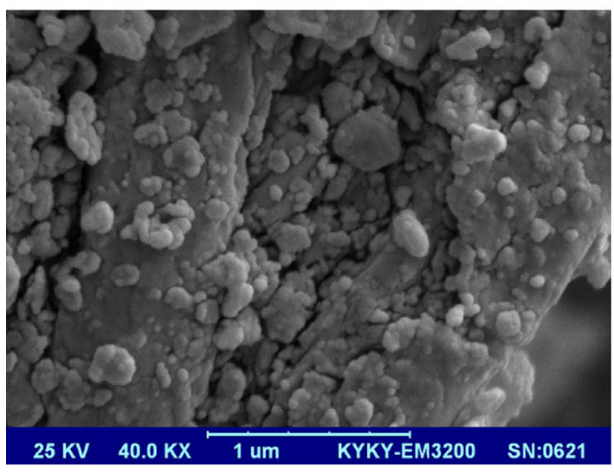

(b)

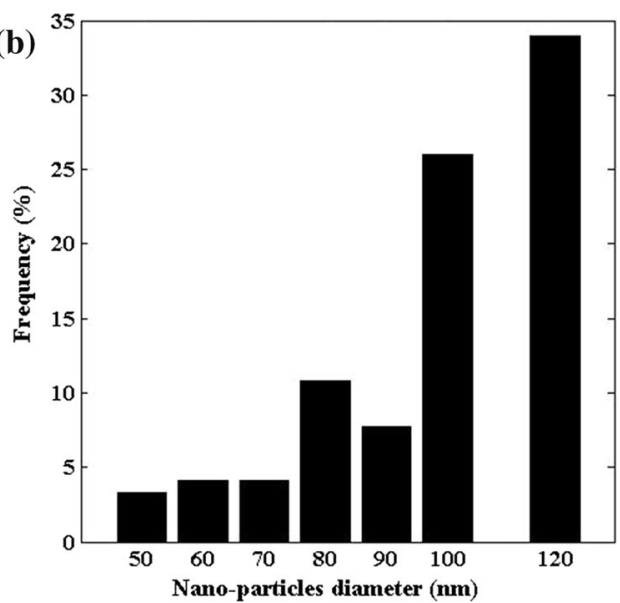

reductions in the biomass such as carbohydrate and protein could supply electrons for nickel bioreduction, with partial release of soluble organics or final oxidized product (Park et al. 2004).

The uptakes observed at higher $\mathrm{pH}$ values indicate that such ligands as carboxylate and sulfonate groups could uptake a smaller number of metal ions (Volesky 1990); in this case, the alga entered heavy metals from ligands. In another study, on the other hand, at low and high $\mathrm{pH}$ values, heavy metals had a higher redox potential and favored metal bioreduction (Esmaeili and Darvish 2014). In addition, reductions in the biomass such as carbohydrate and protein could supply electrons for $\mathrm{Ni}$ (II) bioreduction, with partial release of soluble organics or final oxidized product (Park et al. 2004). According to Fig. 4a, b, the biosorption capacity increased with the increase in $\mathrm{pH}$ to a maximum value of 6 and then declined with further increase in $\mathrm{pH}$ (Esmaeili and Beni 2014).

\section{Effect of biomass dose}

Biosorbent dose has a direct relationship with the removal efficiency. According to Fig. $4 \mathrm{c}$, d, the biosorption capacity curve in both cases has a peak; the maximum biosorption capacity for nickel and cobalt biosorption is observed at biomass doses of 8 and $4 \mathrm{~g} / \mathrm{l}$, respectively, with 91.32 and $88.36 \%$ removal efficiency. In other researches, biosorption of $\mathrm{Pb}^{2+}$ and cadmium was studied using a protonated $S$. glaucescens biomass in a continuous packed-bed column. The maximum capacity of lead by the regenerated biomass was determined to be $0.75 \mathrm{mmol} / \mathrm{g}$, while the same value for the original biomass was $1.24 \mathrm{mmol} / \mathrm{g}$ (Gupta and Rastogi 2009). In our experiment, the optimal dose for removing heavy metals was higher than in other studies where different types of brown algae were employed. Liu et al. (Liu et al. 2009) determined the brown algae optimal dose at $3 \mathrm{~g} / \mathrm{l}$ for nickel biosorption, while in this study a biosorbent dose of $8 \mathrm{~g} / \mathrm{l}$ was determined to be optimal for nickel.

The biomass concentration is an important variable during metal uptake. At a given equilibrium concentration, the biomass takes up more metal ions at lower cell densities than at higher cell densities (Mehta and Gaur 2001). It has been suggested that electrostatic interaction between alginate of S. glaucescens can be a significant factor in the relationship between biomass concentration and metal sorption. In this regard, at a given metal concentration, the lower the biomass concentration in suspension, the higher the metal/biosorbent ratio and the metal retained by a sorbent unit will be, unless the biomass reaches saturation, suggesting that high biomass concentrations can exert a shell effect protecting the active sites from being occupied by the metal. Thus, a smaller amount of metal uptake per biomass unit is enabled (de Rome and Gadd 1987). In the present study, it was noted that the amount of adsorbent significantly influenced the extent of nickel and cobalt biosorption. Different parameters such as the chemical and physical properties of the biosorbent, operating conditions, type and initial concentration of heavy metal, and quality of feed effluent affected the optimum biosorbent dose. The fact that biosorbent dose was higher in this work compared with others could also be related to the preparation procedure applied. 
Fig. 4 Effect of initial solution $\mathrm{pH}$ on biosorption of a Nickel, b Cobalt wastewater (biomass dose of $10 \mathrm{~g} / \mathrm{l}$ for nickel and $4 \mathrm{~g} / \mathrm{l}$ for cobalt, contact time 60 min). Effect of biosorbent dose on biosorption of $\mathbf{c}$ Nickel, d Cobalt wastewater $(\mathrm{pH} 6$, temperature $303.15 \mathrm{~K}$, contact time $60 \mathrm{~min}$ ). Effect of contact time on biosorption capacity for e Nickel, f Cobalt ( $\mathrm{pH} 6$, temperature $293.15,303.15$, and $318.15 \mathrm{~K}$ )
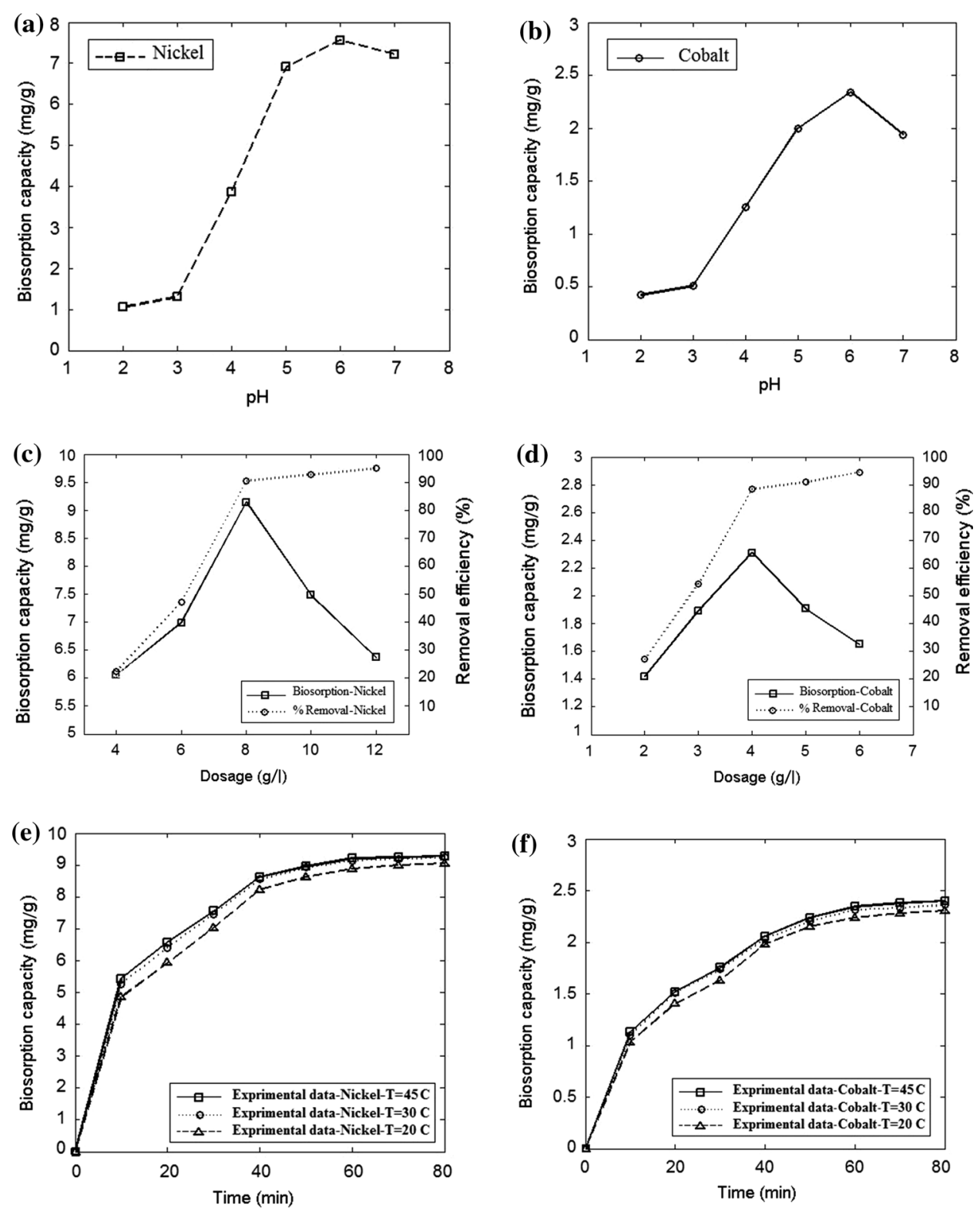

\section{Effect of retention time}

According to Fig. 4e, f, the process was performed at a rapid rate in the first $15 \mathrm{~min}$ and almost $50 \%$ of the initial concentration of heavy metals decreased after this period; then the rate of the process decreased slowly and remained constant in the last $10 \mathrm{~min}$. Also, in this system, equilibrium occurred after $80 \mathrm{~min}$. The initial rapid phase may involve physical adsorption or ion exchange at cell surface, and the subsequent slower phase may involve other mechanisms such as complexation, micro-precipitation, or saturation of binding sites (Gupta and Rastogi 2009).

The SEM was used to observe the surface morphology of nano-biosorbents. The SEM image of brown algae $(S$. glaucescens) nanoparticles is shown in Fig. 3a. As shown, the nanoparticles were produced using a planetary ball mill at $600 \mathrm{rpm}$ for $1 \mathrm{~h}$ to a range of $30-300 \mathrm{~nm}$. Figure $3 \mathrm{~b}$ shows the frequency of different diameters of alginate nanoparticles measured from the SEM images using image 
Table 1 Parameters obtained for first- and second-order kinetic models

\begin{tabular}{|c|c|c|c|c|c|c|c|c|}
\hline \multirow[t]{2}{*}{ Ions } & \multirow[t]{2}{*}{$T(\mathrm{~K})$} & \multirow[t]{2}{*}{$q_{\max }(\mathrm{mg} / \mathrm{g})$} & \multicolumn{3}{|c|}{ Pseudo-first-order model } & \multicolumn{3}{|c|}{ Pseudo-second-order model } \\
\hline & & & $k_{1}\left(\min ^{-1}\right)$ & $q_{e}(\mathrm{mg} / \mathrm{g})$ & $R^{2}$ & $k_{1}(\mathrm{mg} / \mathrm{g} \min )$ & $q_{e}(\mathrm{mg} / \mathrm{g})$ & $R^{2}$ \\
\hline \multirow[t]{3}{*}{ Nickel } & 293 & 9.05 & 0.0697 & 11.161 & 0.974 & 0.191 & 0.322 & 0.587 \\
\hline & 303 & 9.2 & 0.079 & 11.587 & 0.953 & 1.0817 & 0.0491 & 0.436 \\
\hline & 318 & 9.27 & 0.0788 & 11.548 & 0.971 & 0.3161 & 0.1943 & 0.055 \\
\hline \multirow[t]{3}{*}{ Cobalt } & 293 & 2.3 & 0.0654 & 3.097 & 0.958 & 0.555 & 0.110 & 0.557 \\
\hline & 303 & 2.35 & 0.0302 & 3.22 & 0.955 & 0.688 & 0.089 & 0.610 \\
\hline & 318 & 2.4 & 0.0645 & 3.081 & 0.962 & 0.493 & 0.129 & 0.618 \\
\hline
\end{tabular}

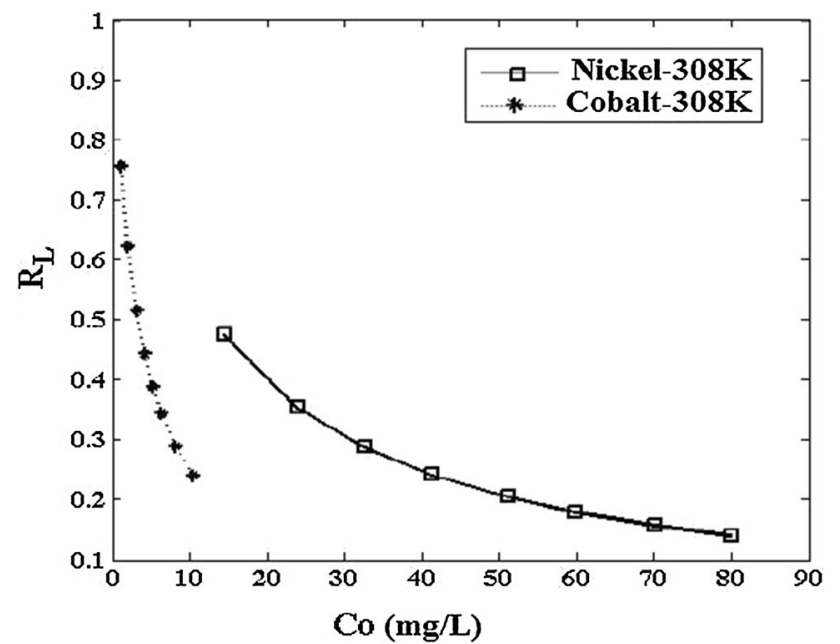

Fig. 5 Dimensionless constant RL

processing software. The average diameter of the alginate nanoparticles was $95.75 \mathrm{~nm}$.

\section{Biosorption process kinetics}

In order to evaluate the biosorption kinetic mechanism, the pseudo-first-order and pseudo-second-order models were applied to fit experimental data. The pseudo-first-order model is expressed as Eq. (1): $\log \left(q_{e}-q_{t}\right)=\log q_{e}-\left(k_{1} / 2.303\right) t$

The pseudo-second-order equation is expressed as Eq. (2):

$\frac{1}{q_{e}-q_{t}}=\frac{1}{q_{e}}+k_{2} t$

where $q_{e}$ is the biosorption capacity at equilibrium $(\mathrm{mg} /$ $\mathrm{g})$ and $q_{t}$ is the biosorption capacity at time $t(\mathrm{~min}) . k_{1}$ $(\mathrm{l} / \mathrm{min})$ and $k_{2}(\mathrm{~g} / \mathrm{mg} \mathrm{min})$ are pseudo-first-order and pseudo-second-order rate constants. The kinetic rate constants are given in Table 1. According to data fitting results, the reaction kinetics with a correlation coefficient greater than 0.95 obeys the pseudo-first-order kinetic model.

\section{Modeling of biosorption isotherms}

The relationship between equilibrium concentrations of heavy metals at liquid phase and the amount of heavy metal uptake in the biosorbent at constant temperature is expressed with different types of sorption isotherms. In this study, Langmuir, Freundlich, and Dubinin-Radushkevich isotherm models were used. The Langmuir isotherm can be used to describe the adsorption of a single layer of an adsorbent (Esmaeili and Beni 2014). The general form of the Langmuir isotherm is:

Table 2 Isotherm parameters for metal biosorption

\begin{tabular}{|c|c|c|c|c|c|c|c|c|c|c|c|}
\hline \multirow[t]{2}{*}{ Ions } & \multirow[t]{2}{*}{$T(\mathrm{~K})$} & \multicolumn{3}{|c|}{ Langmuir isotherm } & \multicolumn{3}{|c|}{ Freundlich isotherm } & \multicolumn{4}{|c|}{$\mathrm{D}-\mathrm{R}$ isotherm } \\
\hline & & $b$ & $q_{\max }$ & $R^{2}$ & $n$ & $K \mathrm{~F}$ & $R^{2}$ & $q_{\mathrm{DR}}$ & $\beta \mathrm{DR}$ & $E$ & $R^{2}$ \\
\hline Nickel & 308 & 0.076 & 28.73 & 0.995 & 1.191 & 2.08 & 0.925 & 0.316 & $2.025 \times 10^{-8}$ & 4.969 & 0.997 \\
\hline Cobalt & 308 & 0.301 & 10.11 & 0.99 & 1.098 & 2.44 & 0.991 & 1.81 & $1.316 \times 10^{-8}$ & 6.164 & 0.999 \\
\hline
\end{tabular}


Table 3 Thermodynamic parameters for metal biosorption

\begin{tabular}{|c|c|c|c|c|c|c|c|c|}
\hline \multirow[t]{2}{*}{ Ions } & \multicolumn{3}{|l|}{$k_{\mathrm{d}}$} & \multirow[t]{2}{*}{$\Delta H^{\circ}(\mathrm{kJ} / \mathrm{mol})$} & \multirow[t]{2}{*}{$\Delta S^{\circ}(\mathrm{J} / \mathrm{mol} \mathrm{K})$} & \multicolumn{3}{|c|}{$\Delta G^{\circ}(\mathrm{kJ} / \mathrm{mol})$} \\
\hline & $20{ }^{\circ} \mathrm{C}$ & $30{ }^{\circ} \mathrm{C}$ & $45^{\circ} \mathrm{C}$ & & & $20^{\circ} \mathrm{C}$ & $30^{\circ} \mathrm{C}$ & $45^{\circ} \mathrm{C}$ \\
\hline Nickel & 9.432 & 11.843 & 12.587 & 8.60 & 48.333 & -5.469 & -6.229 & -6.699 \\
\hline Cobalt & 7.407 & 9.137 & 10.954 & 11.98 & 57.682 & -4.880 & -5.575 & -6.331 \\
\hline
\end{tabular}

$q_{e}=\frac{q_{\mathrm{max}} b C_{e}}{1+b C_{e}}$

where $q_{\max }(\mathrm{mg} / \mathrm{g})$ and $b(1 / \mathrm{mg})$ are Langmuir constants related to the sorption capacity and energy, respectively. Based on the Langmuir isotherm model, a dimensionless constant, commonly known as separation factor $\left(R_{\mathrm{L}}\right)$ defined by Webber and Chakkravorti, can be represented as:

$R_{\mathrm{L}}=\frac{1}{1+K_{\mathrm{L}} C_{0}}$

where $K_{\mathrm{L}}(1 / \mathrm{mg})$ refers to the Langmuir constant. $R_{\mathrm{L}}$ value in the range between zero and one $\left(0<R_{\mathrm{L}}<1\right)$ indicates the biosorption nature to be favorable. As shown in Fig. 5, a lower $R_{\mathrm{L}}$ value reflects that biosorption is more favorable.

The Freundlich model can be used to describe multilayer adsorption as well as nonideal sorption on heterogeneous surfaces (Esmaeili and Beni 2014). The Freundlich isotherm is expressed as:

$q_{e}=K_{\mathrm{F}} C_{e}^{1 / n}$

where $K_{\mathrm{F}}(\mathrm{mg} / \mathrm{g})$ and $n$ are the Freundlich constants related to the temperature and intensity of the sorbent, respectively.

The Dubinin-Radushkevich equation can be used to differentiate the physical adsorption of metal ions from chemical adsorption (Esmaeili and Beni 2014). The nonlinearized form of the Dubinin-Radushkevich equation is

$q_{e}=q_{\mathrm{DR}} \exp \left(-\beta_{\mathrm{DR}} \varepsilon^{2}\right)$

where $q_{\mathrm{DR}}$ is the maximum adsorption capacity ( $\mathrm{mmol} / \mathrm{g}$ ), $\beta_{\mathrm{DR}}$ is the activity coefficient related to adsorption free energy $(\mathrm{mol} / \mathrm{J})^{2}$, and $\varepsilon$ is the polanyi potential:

$\varepsilon=\mathrm{RT} \operatorname{Ln}\left(1+\frac{1}{C_{e}}\right)$

where $R$ is the gas constant $(8.314 \mathrm{~J} / \mathrm{mol} \mathrm{K})$ and $T$ is the absolute temperature $(\mathrm{K})$. The mean adsorption energy $(E$; $\mathrm{kJ} / \mathrm{mol}$ ) is as follows:
$E=\left[\frac{1}{\sqrt{-2 \beta_{\mathrm{DR}}}}\right]$

Chemical ion exchange is indicated by values of $E$ ranging from 8 to $16 \mathrm{~kJ} / \mathrm{mol}$, whereas values of $\mathrm{E}$ less than $8 \mathrm{~kJ} / \mathrm{mol}$ indicate a physical ion exchange. As can be seen in Table 2, by fitting the experimental data, when $E$ value is $E<8 \mathrm{~kJ} / \mathrm{mol}$, the biosorption process is of physical nature. According to biosorption isotherm data analysis as shown in Table 2, it was found that Langmuir and D-R isotherm models with $R^{2}>0.99$ fitted the equilibrium data for both nickel and cobalt ion biosorption. We used the Freundlich adsorption isotherm theory model, which assumes that the adsorption takes place at specific homogeneous sites within the adsorbent. We also employed the Langmuir and DubininRadushkevich isotherm model, which is based on adsorption on a heterogeneous surface. The same set of experimental data was used for both models. Table 2 shows that the data could be well modeled using the Langmuir and Dubinin-Radushkevich adsorption isotherm.

The Langmuir and Dubinin-Radushkevich constant (Table 2) is dependent on experimental conditions such as solution $\mathrm{pH}$. Another important factor in evaluating adsorbent performance is the initial gradient of the adsorption isotherm, since it indicates the adsorbent affinity at metal concentrations.

\section{Thermodynamic parameters}

Thermodynamic parameters including the change in Gibbs free energy $\left(\Delta G^{\circ}\right)$, enthalpy $\left(\Delta H^{\circ}\right)$, and entropy $\left(\Delta S^{\circ}\right)$ were calculated from following equations:

$\Delta G^{\circ}=-\mathrm{RT} \operatorname{Ln} k_{\mathrm{d}}$
$k_{\mathrm{d}}=\lim _{\substack{C_{\mathrm{el}} \rightarrow 0 \\ \text { time } \rightarrow \infty}} \frac{C_{\mathrm{es}}}{C_{\mathrm{el}}}$ 
$k_{\mathrm{d}}=\frac{C_{\mathrm{es}}}{C_{\mathrm{el}}}=\frac{C_{0}-C_{e}}{C_{e}}$

where $R$ is the universal gas constant $(8.314 \mathrm{~J} / \mathrm{mol} \mathrm{K}), \mathrm{T}$ is the absolute temperature $(K)$, and $k_{\mathrm{d}}$ is the biosorption equilibrium constant or distribution coefficient. $C_{\mathrm{es}}$ and $C_{\mathrm{el}}$ are the values of ion equilibrium concentration in the solid and liquid phase $(\mathrm{mg} / \mathrm{l})$. The relationship between the equilibrium constant $\left(k_{\mathrm{d}}\right)$ and temperature is given by the Van't Hoff equation:

$\ln k_{\mathrm{d}}=\frac{\Delta S^{\circ}}{R}-\frac{\Delta H^{\circ}}{\mathrm{RT}}$

As shown in Table 3 , the $\Delta G^{\circ}$ value was negative. This indicates the feasibility and spontaneity of metal biosorption. The positive value of $\Delta H^{\circ}$ proved the endothermic interaction; therefore, the biosorption capacity at equilibrium must increase with increasing temperature. The positive value of $\Delta S^{\circ}$ confirmed the increased randomness of solid/liquid interface during the biosorption process.

\section{Conclusion}

In this study, brown algae (S. glaucescens) nanoparticles were prepared by using a planetary ball mill. The abilities of nano-biosorbents to adsorb nickel and cobalt were investigated in a membrane reactor. It was seen that biosorption of metal ions is strongly dependent on the $\mathrm{pH}$ of the solution. The optimum $\mathrm{pH}$ level for the biosorption of nickel and cobalt was found to be 6. Equilibrium behavior of nickel and cobalt ions was analyzed by Langmuir, Freundlich, and Dubinin-Radushkevich isotherm models. The Langmuir and Dubinin-Radushkevich equations were found to be better models for representing the equilibrium data. The suitability of the first- and second-order dynamic equations and the model for the kinetic data were also discussed. The pseudo-first-order dynamic model agreed very well with the biosorption of nickel and cobalt onto the brown algae nanoparticle. Thermodynamic constants for biosorptions were also evaluated. The calculated thermodynamic parameters showed the feasibility, endothermic, and spontaneous nature of the metal ion biosorption.

Acknowledgments The authors wish to thank Miss Seyedeh Flour Mazhar, Laboratory of Microbiology, North Tehran Branch, Islamic Azad University (Tehran, Iran), for her assistance.

\section{References}

Bai RS, Abraham TE (2002) Studies on enhancement of Cr(VI) biosorption by chemically modified biomass of Rhizopus nigricans. Water Res 36:1224-1236

Daneshvar E, Kousha M, Jokar M, Koutahzadeh N, Guibal E (2012) Acidic dye biosorption onto marine brown macroalgae: isotherms, kinetic and thermodynamic studies. Chem Eng J 204:225-234

de Rome L, Gadd GM (1987) Copper adsorption by Rhizopus arrhizus, Cladosporium resinae and Penicillium italicum. Appl Microbiol Biotechnol 26:84-90

Esmaeili A, Beni AA (2014) A novel fixed-bed reactor design incorporating an electrospun PVA/chitosan nanofiber membrane. J Hazard Mater 280:788-796

Esmaeili A, Darvish M (2014) Evaluation of the marine alga Sargassum glaucescens for the adsorption of $\mathrm{Zn}$ (II) from aqueous solutions. Water Qual Res J Can 49(4):339-345

Esmaeili A, Sadeghi E (2014) The efficiency of Penicillium commune for bioremoval of industrial oil. Int J Environ Sci Technol 11:1271-1276

Esmaeili A, Ghasemi S, Zamani F (2012a) Investigation of Cr(VI) adsorption by dried brown algae Sargassum sp. and its activated carbon. Iran J Chem Chem Eng 31(4):11-19

Esmaeili A, Kalantari M, Saremnia B (2012a) Biosorption of Pb(II) from aqueous solutions by modified of two kinds of marine algae, Sargassum glaucescens and Gracilaria corticata. Polish J Chem Technol 14:22-28

Esmaeili A, Saremnia B, Kalantari M (2012c) Removal of mercury(II) from aqueous solutions by biosorption on the biomass of Sargassum glaucescens and Gracilaria corticata. Arab J Chem. doi:10.1016/j.arabjc.2012.01.008

Gupta V, Rastogi A (2009) Biosorption of hexavalent chromium by raw and acid-treated green alga Oedogonium hatei from aqueous solutions. J Hazard Mater 163:396-402

Kalyani S, Srinivasa Rao P, Krishnaiah A (2004) Removal of nickel(II) from aqueous solutions using marine macroalgae as the sorbing biomass. Chemosphere 57:1225-1229

Kleinübing S, Da Silva E, Da Silva M, Guibal E (2011) Equilibrium of $\mathrm{Cu}(\mathrm{II})$ and $\mathrm{Ni}(\mathrm{II})$ biosorption by marine alga Sargassum filipendula in a dynamic system: competitiveness and selectivity. Bioresour Technol 102:4610-4617

Koedrith P, Kim H, Weon J-I, Seo YR (2013) Toxicogenomic approaches for understanding molecular mechanisms of heavy metal mutagenicity and carcinogenicity. Int $\mathrm{J}$ Hyg Environ Health 216:587-598

Liu Y, Cao Q, Luo F, Chen J (2009) Biosorption of $\mathrm{Cd}^{2+} \mathrm{Cu}^{2+} \mathrm{Ni}^{2+}$ and $\mathrm{Zn}^{2+}$ ions from aqueous solutions by pretreated biomass of brown algae. J Hazard Mater 163:931-938

Mehta SK, Gaur JP (2001) Removal of Ni and $\mathrm{Cu}$ from single and binary metalsolutions by free and immobilized Chlorella vulgaris. Eur J Protistol 37:261-271

Montazer-Rahmati MM, Rabbani P, Abdolali A, Keshtkar AR (2011) Kinetics and equilibrium studies on biosorption of cadmium, lead, and nickel ions from aqueous solutions by intact and chemically modified brown algae. J Hazard Mater 185:401-407

Nurbaş Nourbakhsh M, Kiliçarslan S, Ilhan S, Ozdag H (2002) Biosorption of $\mathrm{Cr}^{6+} \mathrm{Pb}^{2+}$ and $\mathrm{Cu}^{2+}$ ions in industrial waste water on Bacillus sp. Chem Eng J 85:351-355 
Pahlavanzadeh H, Keshtkar A, Safdari J, Abadi Z (2010) Biosorption of nickel(II) from aqueous solution by brown algae: equilibrium, dynamic and thermodynamic studies. J Hazard Mater 175:304-310

Park D, Yun Y-S, Park JM (2004) Reduction of hexavalent chromium with the brown seaweed Ecklonia biomass. Environ Sci Technol $38: 4860-4864$
Pinto PX, Al-Abed SR, Reisman DJ (2011) Biosorption of heavy metals from mining influenced water onto chitin products. Chem Eng J 166:1002-1009

Volesky B (1990) Biosorption of heavy metals. CRC Press, Boca Raton

Wang J, Chen C (2009) Biosorbents for heavy metals removal and their future. Biotechnol Adv 27:195-226 